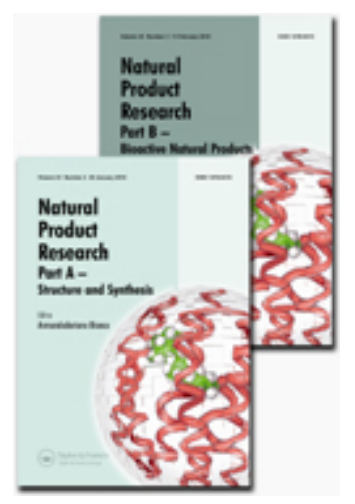

\title{
Antiproliferative activity of aqueous and polyphenol-rich extracts of Larrea divaricata Cav. upon a melanoma cell line
}

\begin{tabular}{|c|c|}
\hline Journal: & Natural Product Research \\
\hline Manuscript ID & GNPL-2021-1181.R4 \\
\hline Manuscript Type: & Short Communication \\
\hline $\begin{array}{r}\text { Date Submitted by the } \\
\text { Author: }\end{array}$ & 31 -Aug-2021 \\
\hline Complete List of Authors: & $\begin{array}{l}\text { Martino, Renzo; Universidad de Buenos Aires Facultad de Farmacia y } \\
\text { Bioquimica } \\
\text { Barreiro Arcos, María; Pontificia Universidad Catolica Argentina } \\
\text { Peralta, Ignacio; Universidad de Buenos Aires Facultad de Farmacia y } \\
\text { Bioquimica } \\
\text { Marrassini, Carla; Universidad de Buenos Aires Facultad de Farmacia y } \\
\text { Bioquimica, } \\
\text { Saint Martin, Elina; Universidad de Buenos Aires Facultad de Farmacia y } \\
\text { Bioquimica } \\
\text { Cogoi, Laura; Universidad de Buenos Aires Facultad de Farmacia y } \\
\text { Bioquimica } \\
\text { Cremaschi, Graciela; Pontificia Universidad Catolica Argentina } \\
\text { Alonso, Maria; Universidad de Buenos Aires Facultad de Farmacia y } \\
\text { Bioquimica } \\
\text { Anesini, Claudia; Universidad de Buenos Aires Facultad de Farmacia y } \\
\text { Bioquimica }\end{array}$ \\
\hline Keywords: & $\begin{array}{l}<\mathrm{i}>\text { Larrea divaricata }</ \mathrm{i}>\text { Cav, melanoma B16F10 cell line, } \\
\text { antiproliferative activity, STAT3, apoptosis }\end{array}$ \\
\hline
\end{tabular}

\section{SCHOLARONE ${ }^{\text {M }}$ Manuscripts}




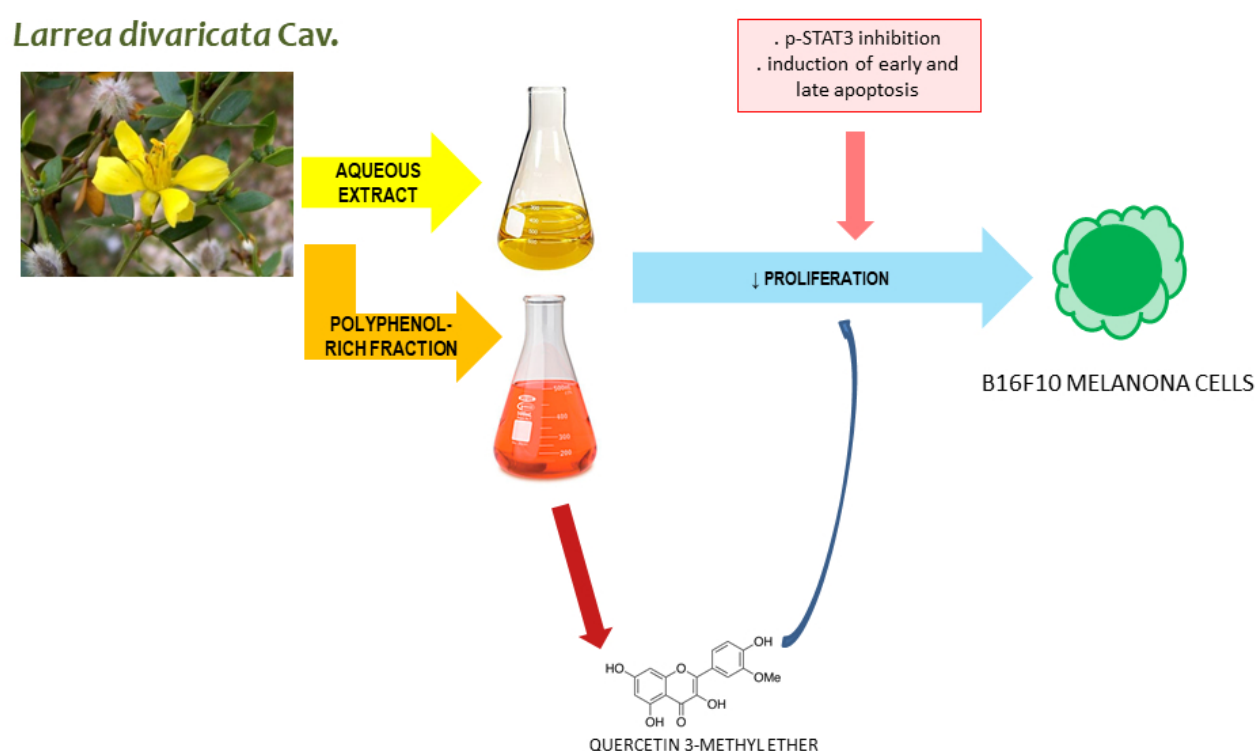

254×190mm (96 x 96 DPI) 


\section{Antiproliferative activity of aqueous and polyphenol-rich extracts of Larrea divaricata Cav. on a melanoma cell line}

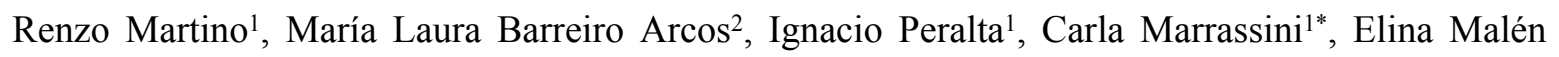
Saint Martin ${ }^{1}$, Laura Cogoi $^{1}$, Graciela Cremaschi ${ }^{2}$, María Rosario Alonso ${ }^{1}$, Claudia Anesini ${ }^{1}$ 1 Facultad de Farmacia y Bioquímica, Instituto de la Química y Metabolismo del Fármaco (IQUIMEFA), Consejo Nacional de Investigaciones Cientificas y Técnicas (CONICET), Universidad de Buenos Aires. Junín 956, 2 do piso, Buenos Aires, Argentina.

2 Instituto de Investigación Biomédica (BIOMED), Consejo de Investigaciones Científicas y Técnicas (CONICET), Universidad Católica Argentina (UCA). Avda. Alicia Moreau de Justo 1600, 3er piso, Buenos Aires, Argentina.

\footnotetext{
*Correspondence to:

Dr Carla Marrassini

IQUIMEFA-UBA-CONICET

Faculty of Pharmacy and Biochemistry, University of Buenos Aires.

Junín 956, 2do piso, Buenos Aires, Argentina. Phone number: 00541152874286

E-mail: $\underline{\text { cmarra@ffyb.uba.ar }}$
} 


\title{
Antiproliferative activity of aqueous and polyphenol-rich extracts of Larrea divaricata Cav.
} upon a melanoma cell line

\begin{abstract}
Most of the deaths from skin cancer are caused by melanoma, a malignancy in which STAT3 plays a crucial role. The inhibition of STAT3 is considered a potential target to induce cell death, tumor regression and metastasis inhibition. The objective of this work was to evaluate the activity of the aqueous extract of Larrea divaricata (Aq), a fraction rich in polyphenols (EA), and the isolated compound quercetin-3-methyl ether (Q3ME) on B16F10 melanoma cells. The effects of Aq, EA and Q3ME were assessed on B16F10 cells by determining the proliferation, viability, apoptosis induction and the expression and phosphorylation of STAT3. The phytochemical composition of the extracts was determined by High Performance Liquid Chromatography. Aq, EA and Q3ME presented antiproliferative activity on B6F10 cells through p-STAT3 inhibition and early and late apoptosis induction $\left(\mathrm{EC}_{50} \mathrm{EA}=\leq 0.1 \mu \mathrm{g} / \mathrm{ml}\right.$; $\mathrm{Aq}=316 \pm 30 \mu \mathrm{g} / \mathrm{ml}$; Q3ME $\left.=<0.1 \mu \mathrm{g} / \mathrm{ml}\right)$. L. divaricata could be considered for the development of adjuvant phytotherapies in melanoma treatment.
\end{abstract}

Keywords: Larrea divaricata Cav., melanoma B16F10 cell line, antiproliferative activity, STAT3, apoptosis.

\section{Introduction}

According to the World Health Organization (WHO), 80\% skin cancer deaths are due to melanoma. In 50-90\% of melanomas, the Janus kinase signal transducer and activator of transcription, STAT3, is constitutively activated and is considered a potential treatment target to induce cell death, tumor regression and inhibition of metastasis (Kortylewski et al. 2005; Kamran et al. 2013).

Polyphenol-rich natural products have been reported to exert an antiproliferative activity on melanoma cells (Stevanato et al. 2014; Tong and Young 2014). Since the synthetic agents used for melanoma treatment can cause severe adverse effects, natural safe agents obtained from plant extracts should be considered. Larrea divaricata (Zygophyllaceae) is an autochthonous South American plant widely distributed in Argentina and used in popular medicine for the treatment of inflammatory diseases and cancer. This species produces polyphenol compounds such as hydroxycinnamic acid, flavonoids and lignans (Lorenzo et al. 2020). It has previously been demonstrated that an aqueous extract (Aq) of the leaves and a polyphenol-rich sub-fraction obtained by extraction with ethyl acetate (EA) exert antiproliferative effects on the EL-4 lymphoma cell line (Martino et al. 2013; Martino et al. 2016). However, the effect of these extracts has not been studied 
on melanoma cells. This work aimed at elucidating the anti-proliferative mechanism of action of Aq and EA on melanoma cells. The results obtained would be useful to develop natural novel phytomedicines to be used along with the adjuvant therapy for melanoma.

\section{Results and Discussion}

In this work, an aqueous extract and a polyphenol-rich extract from L. divaricata exerted antiproliferative effects on a melanoma cell line by inhibiting the phosphorylation of STAT3, and inducing early and late apoptosis.

The lignan nor-dihydroguaiaretic acid (NDGA) (retention time: $47 \mathrm{~min}$ ), 4-hydroxybenzoic acid (4HBA) (retention time: $12 \mathrm{~min}$ ), together with other flavonoids (retention times between 24-25 min) were identified and quantified by HPLC-UV in Aq and EA.Quercetin-3-methyl ether (Q3ME) was only detected in EA (chromatograms not shown). As it can be seen in Table S1, the amount of polyphenols, Q3ME, NDGA and the 4-HBA, were greater in EA than in Aq.

Aq and EA inhibited B16F10 cell proliferation in a concentration-response manner and decreased cell viability (Figures S1A and B), but a dependency of the latter effect with the extract concentration could be established neither with Aq nor with EA. The highest inhibitory capacity was observed with EA (Table S2). All compounds exerted antiproliferative activity $(\mathrm{p}<0.001$ $\mathrm{p}<0.0001)$. 4-HBA was the least active compound and Q3ME, which also decreased cell viability $(p<0.0001)$, was found to be the most potent (Figure S1C, D and E, Table S2). Taking into account these results, Q3MEwas used for further studies.

The flow cytometry analysis demonstrated that Aq, EA and Q3ME at $10 \mu \mathrm{g} / \mathrm{ml}$ were able to induce a significant decrease of cell viability, an increase in the number of cells in early apoptosis ( $\mathrm{p}<$ $0.0001)$, late apoptosis $(p<0.01)$ as well as necrotic ones $(p<0.05, p<0.001)$ (Figure S1E). It had been previously demonstrated that Aq inhibited the proliferation of the BW 5147 lymphoma cell line and that EA inhibits EL-4 lymphoma cell line by inducing apoptosis mediated by ROS and NO (Davicino et al. 2010; Martino et al. 2013; Martino et al. 2016). Q3ME,4-HBA and NDGA had also shown antiproliferative effects on dermal tumor cells and breast cancer cells (Kubow et al. 2000; Li et al. 2012; Wang et al. 2018).

It is known that the activation of STAT3 leads to the synthesis of molecules involved in malignant transformation and since several clinical trials are being undertaken to study the effectiveness of STAT3 inhibitors, including natural molecules (Siveen et al. 2014), the interaction of the most active drugs, EA and Q3ME, with STAT3 was analyzed. 
The STAT3 proliferative dependency of the melanoma cell line was confirmed, since the STAT3 inhibitor 5,15 DPP decreased cell proliferation and STAT3 phosphorylation, while the proinflammatory cytokine IL-6 exerted opposite effects (Figure S2 A, C and D).The anti-proliferative effect of EA and Q3ME was mediated by the inhibition of STAT3 phosphorylation (Figure S2 C and D). The latter finding was confirmed by the fact that IL-6 was able to revert the antiproliferative effect induced by EA and Q3ME (Figure S2B).The inhibition of STAT3 phosphorylation could be related to the induction of apoptosis. It has previously been reported that quercetin regulates the STAT3 pathway in melanoma cells by inhibiting its phosphorylation/activation (Cao et al. 2014). Plant extracts containing quercetin and kaempferol exert antiproliferative effects on B16F10melanoma cells by inducing late apoptosis and inhibiting the phosphorylation of STAT3. These effects were observed with the herbal formula "Huai-Hua-San", which contains Sophorae flos and Gardeniae fructus ethanolic extracts, which were found to decrease viability with an $\mathrm{EC}_{50}$ value of around $400 \mu \mathrm{g} / \mathrm{ml}$, a value that was higher than that found for $L$. divaricata extracts (Li et al. 2021).

\section{Experimental}

See supplementary material.

\section{Conclusions}

The results presented in this work serve as the basis for future in vivo studies in induced melanoma models to determine the effect of aqueous or polyphenol-rich extracts form L. divaricata as coadjutant phytotherapies for the treatment of this disease.

\section{Competing interests}

The authors declare no competing interests.

\section{Funding}

This work was supported by PIP 00067 CONICET and UBACYT from Buenos Aires University (20020130100686BA).

\section{References}

Cao HH, Tse AK, Kwan HY, Yu H, Cheng CY, Su T, Fong WF, Yu ZL. 2014. Quercetin exerts anti-melanoma activities and inhibits STAT3 signaling. Biochem Pharmacol. 87(3):424-434.

Davicino R, Manuele MG, Turner S, Ferraro G, Anesini C. 2010. Antiproliferative activity of Larrea divaricata Cav. on lymphoma cell line: participation of hydrogen peroxide in its action. Cancer Invest. 28(1):13-22. doi: 10.3109/07357900902849665.

Kamran MZ, Gude RP. 2013. Pentoxifylline inhibits melanoma tumor growth and angiogenesis by targeting STAT3 signaling pathway. Biomed Pharmacother. 67(5):399-405. 
Kortylewski M, Jove R, Yu H. 2005. Targeting STAT3 affects melanoma on multiple fronts. Cancer Metastasis Rev. 24(2): 315-327. doi: 10.1007/s10555-005-1580-1.

Kubow S, Woodward TL, Turner JD, Nicodemo A, Long E, Zhao X. 2000. Lipid peroxidation is associated with the inhibitory action of all-trans-retinoic acid on mammary cell transformation. Anticancer Res. 20(2A):843-8.

Li J, Mottamal M, Li H, Liu K, Zhu F, Cho YY, Sosa CP, Zhou K, Bowden GT, Bode AM, Dong Z. 2012. Quercetin-3-methyl ether suppresses proliferation of mouse epidermal JB6 P1 cells by targeting ERKs. Carcinogenesis. 33(2):459-465. doi:10.1093/carcin/bgr281.

Li JK, Chou JY, Yin CL, Fu XQ, Wu Y, Chen YJ, Bai JX, Wu JY, Liang C, Yu ZL. 2021. A twoherb formula inhibits STAT3 signaling and exerts anti-melanoma effects in cell and animal models. J Ethnopharmacol. 25: 268:113671. doi: 10.1016/j.jep.2020.113671.

Lorenzo ME, Casero CN, Gómez PE, Segovia AF, Figueroa LC, Quiroga A, Werning ML, Wunderlin DA, Baroni MV. 2020. Antioxidant characteristics and antibacterial activity of native woody species from Catamarca, Argentina. Nat Prod Res. 13:1-6. doi: 10.1080/14786419.2020.1839461

Martino R, Barreiro Arcos ML, Alonso MR, Sülsen V, Cremaschi G, Anesini C. 2016. Polyphenol rich fraction from Larrea divaricata and its main flavonoid quercetin-3-methyl ether induce apoptosis in lymphoma cells through nitrosative stress. Phytother Res. 30(7):1128-36. doi: 10.1002/ptr.5615.

Martino R, Sülsen V, Alonso MR, Anesini C. 2013. A fraction rich in phenyl propanoids from Larrea divaricata aqueous extract is capable of inducing apoptosis, in relation to $\mathrm{H} 2 \mathrm{O} 2$ modulation, on a murine lymphoma cell line. Leuk Res. 37(9): 1137-1143. Doi: 10.1016/06.004.

Siveen KS, Sikka S, Surana R, Dai X, Zhang J, Kumar AP, Tan BK, Sethi G, Bishayee A. 2014. Targeting the STAT3 signaling pathway in cancer: role of synthetic and natural inhibitors. Biochim Biophys Acta: Rev Cancer. 1845(2):136-154.

Stevanato R, Bertelle M, Fabris S. 2014. Photoprotective characteristics of natural antioxidant polyphenols. Regul Toxicol Pharmacol. 69(1):71-77.

Tong LX, Young LC. 2014. Nutrition: the future of melanoma prevention? J Am Acad Dermatol. 71(1):151-160.

Wang XN, Wang KY, Zhang XS, Yang C, Li XY. 2018. 4-Hydroxybenzoic acid (4-HBA) enhances the sensitivity of human breast cancer cells to adriamycin as a specific HDAC6 inhibitor by promoting HIPK2/p53 pathway. Biochem Biophys Res Commun. 504(4):812-819. doi: 10.1016/j.bbrc.2018.08.043. 
Antiproliferative activity of aqueous and polyphenol-rich extracts of Larrea

\title{
divaricata Cav. on a melanoma cell line
}

Renzo Martino, María Laura Barreiro Arcos, Ignacio Peralta, Carla Marrassini, Elina Malén Saint Martin, Laura Cogoi, Graciela Cremaschi, María Rosario Alonso, Claudia Anesini

\begin{abstract}
Most of the deaths from skin cancer are caused by melanoma, a malignancy in which STAT3 plays a crucial role. The inhibition of STAT3is considered a potential target to induce cell death, tumor regression and metastasis inhibition. The objective of this work was to evaluate the activity of the aqueous extract of Larrea divaricata (Aq), a fraction rich in polyphenols (EA), and the isolated compound quercetin-3-methyl ether (Q3ME) on B16F10 melanoma cells. The effects of Aq, EA and Q3ME were assessed onB16F10 cells by determining the proliferation, viability, apoptosis induction and the expression and phosphorylation of STAT3.The phytochemical composition of the extracts was determined by High Performance Liquid Chromatography. Aq, EA and Q3ME presented antiproliferative activity on B6F10 cells through p-STAT3 inhibition and early and late apoptosis induction $\left(\mathrm{EC}_{50} \mathrm{EA}=\leq 0.1 \mu \mathrm{g} / \mathrm{ml} ; \mathrm{Aq}=\right.$ $316 \pm 30 \mu \mathrm{g} / \mathrm{ml}$; Q3ME $=<0.1 \mu \mathrm{g} / \mathrm{ml}$ ). L. divaricata could be considered for the development of adjuvant phytotherapies in melanoma treatment.
\end{abstract}

\section{Experimental}

\section{Plant material and preparation of extracts}

Larrea divaricata Cav. (Zygophyllaceae) leaves were obtained from the wild by Dr Ignacio Peralta, during January 2017, in Córdoba, Argentina, Rio Dolores district, quarter Aguas Azules (Sector B), Capilla del Monte, Department of Punilla (land register nomenclature: Dep. 23- Ped. 01- Pueblo 06- Circ. 05- Secc. 02- Manzana 054- Parcela 003)and identified by Dr Gustavo Giberti† and Hernán Gerónimo Bach. A voucher specimen (BAFC no. 38) was deposited at the Museum of Pharmacobotany, School of Pharmacy and Biochemistry, University of Buenos Aires. No state permissions were necessary to collect the sample. The plant material was airdried at $25^{\circ} \mathrm{C}$. A $7.5 \%$ aqueous extract was prepared by boiling the leaves in distilled water for $20 \mathrm{~min}$. The extract was then filtered using a Buchner funnel and a125 mm no. 42 Whatman paper and lyophilized. The final yield was $26.6 \mathrm{~g} / 100 \mathrm{~g}$ of plant material. A fraction enriched in flavonoids was obtained by liquid-liquid partition of Aq with dichloromethane (DM) and ethyl acetate (Davicino et al. 2011). Aq and EA (obtained from ethyl acetate) were used for subsequent studies.

\section{HPLC analysis}


The HPLC analysis was performed in a Varian Pro Star instrument equipped with a Rheodyne injection valve $(20 \mu \mathrm{l})$ and a photodiode array detector set at $280 \mathrm{~nm}(\mathrm{NDGA})$ and $260 \mathrm{~nm}$ quercetin 3-methyl ether (Q3ME). A Phenomenex-Kinetex (no. 00G-4605-EO, $5 \mu \mathrm{m} \mathrm{XB-C18}$ 100A, size: $250 \mathrm{mmx} 4.6 \mathrm{~mm}$, surface area: $200 \mathrm{~m}^{2} / \mathrm{g}$ ) was used. For the identification and quantification of NDGA, samples were eluted with a gradient of solution A (water and acetic acid, 98:2), and solution B (methanol and acetic acid, 98:2). The gradient was from 15\% B to $40 \% \mathrm{~B}$ in $30 \mathrm{~min}, 40 \% \mathrm{~B}$ to $75 \% \mathrm{~B}$ in $10 \mathrm{~min}, 75 \% \mathrm{~B}$ to $85 \% \mathrm{~B}$ in $5 \mathrm{~min}$ and $100 \% \mathrm{~B}$ in $5 \mathrm{~min}$. The flow rate was $1.2 \mathrm{ml} / \mathrm{min}$. A calibration curve of NDGA was obtained by injecting $20 \mu \mathrm{l}$ of solutions ranging from $2 \mu \mathrm{g} / \mathrm{ml}$ to $200 \mu \mathrm{g} / \mathrm{ml}$. (Pearson's correlation coefficient: $\mathrm{r}^{2}=0.9988$ ).

For the identification and quantification of Q3ME and 4-hydroxybenzoic acid (4-HBA), three chromatographic systems were used: System 1 was the same as that described for the quantification of NDGA. In system 2, a mixture of water/methanol/phosphoric acid (100:100:1) was used as mobile phase. In system 3, two mobile phases were used: solution A was a waterphosphoric acid (0.5\%) mixture and solution $\mathrm{B}$ was a methanol-phosphoric acid $(0.5 \%)$ mixture. The elution profile was $100 \%$ A to $25 \% \mathrm{~A}$ in $30 \mathrm{~min}, 25 \% \mathrm{~A}$ to $0 \% \mathrm{~A}$ in $2 \mathrm{~min}$, and back to the initial conditions.

NDGA, 4-HBA and Q3MEpure standards (Sigma, USA) were used for identification and quantification by comparing retention times and by plotting peak areas, respectively. Aq and EA at $10 \mathrm{mg} / \mathrm{ml}$ and the pure standard were dissolved in methanol:water (70:30). Chromatograms are not shown.

\section{Quantification of total polyphenols}

Polyphenols were determined spectrophotometrically by the Folin-Ciocalteu's method using gallic acid as standard (Hosseinzadeh et al. 2013). Aq and EA were weighed and dissolved in distilled water. One $\mathrm{ml}$ of each extract was transferred to separate tubes containing $7.0 \mathrm{ml}$ of distilled water, $0.5 \mathrm{ml}$ of Folin-Ciocalteu's reagent, and $1.5 \mathrm{ml}$ of a $20 \%$ anhydrous sodium carbonate solution. Mixtures were left at room temperature for $60 \mathrm{~min}$ and then the absorbance was measured at $765 \mathrm{~nm}$. The concentration of polyphenols in samples was calculated from a standard curve of gallic acid ranging from 10 to $50 \mu \mathrm{g} / \mathrm{ml}$ (Pearson's correlation coefficient: $\mathrm{r}^{2}$ $=0.9996)$. Results were expressed as $\mathrm{mg} \mathrm{GAE} / \mathrm{g}$ extract.

\section{Cells and assays}

\subsection{Cell culture conditions}

The melanoma ATCC cell line B16F10 was cultured at 3x $10^{5}$ cells $/ \mathrm{ml}$ in RPMI 1640 medium supplemented with $10 \%$ of fetal calf serum (Sigma, St. Louis, MO, USA), 2 nM of L-glutamine, $100 \mathrm{IU} / \mathrm{ml}$ penicillin and $100 \mu \mathrm{g} / \mathrm{ml}$ streptomycin (Sigma, St. Louis, MO, USA).

\subsection{Proliferation assays}


The effect of the extracts and isolated compounds on cell proliferation was evaluated by the tritiated thymidine $[3 \mathrm{H}] \mathrm{TdR}$ uptake assay. Cells were pulsed with $[3 \mathrm{H}] \mathrm{TdR}(20 \mathrm{Ci} / \mathrm{mmol})$ for the last $6 \mathrm{~h}$ of incubation as previously described (Anesini et al. 1996).

B16F10 cells were incubated alone or in the presence of different concentrations of either EA, Aq, Q3ME, 4-HBA or NDGA. B16F10 cells were also incubated in the presence of either 5,15 diphenylporphirin (5,15-DPP) (Sigma, St. Louis, MO, USA), a STAT3 inhibitor, and IL-6 (10 $\mathrm{ng} / \mathrm{ml}$, Sigma, St. Louis, MO, USA), a STAT3 activator, and $10 \mu \mathrm{g} / \mathrm{ml} \mathrm{Aq,} 10 \mu \mathrm{g} / \mathrm{ml}$ EA or 10 $\mu \mathrm{g} / \mathrm{ml}$ Q3ME. The optimal incubation time $(24 \mathrm{~h})$ was previously determined by kinetics studies. Results were expressed as cell proliferation inhibition (\%) and cell proliferation (\%). Data represent the mean \pm SEM of three experiments performed in triplicate.

The $\mathrm{EC}_{50}$ values for the antiproliferative activity were calculated from concentration-response curves employing a mathematical method based on the right-angled triangle principle according to the following formula:

$\mathrm{EC}_{50}=$ anti $\log [\mathrm{D}-[(\mathrm{A}-50 \%$ max response $) .(\mathrm{D}-\mathrm{C})] /(\mathrm{A}-\mathrm{B})$

where $\mathrm{A}$ is the response just above the $50 \%$ maximum response; $\mathrm{B}$ is the response just below the $50 \%$ maximum response; $\mathrm{D}=\log$ concentration corresponding to $\mathrm{A} ; \mathrm{C}=\log$ concentration corresponding to B (Alexander et al. 1999).

\subsection{Viability assays}

The effect of Aq, EA and Q3ME at $0.1 \mu \mathrm{g} / \mathrm{ml}, 1 \mu \mathrm{g} / \mathrm{ml}, 10 \mu \mathrm{g} / \mathrm{ml}$ and $100 \mu \mathrm{g} / \mathrm{ml}$ on cell viability for $24 \mathrm{~h}$ was determined by the Trypan blue exclusion method. Briefly, the cell suspension was mixed with $0.4 \%$ Trypan blue in a $1: 9$ ratio and the mixture was transferred to a Neubauer hemocytometer to determine the number of viable and non-viable cells. Viability was expressed as \%Viable cells $=[$ number of viable cells /number of total cells $]$ x 100

\section{Flow cytometry analysis}

The induction of apoptosis in the tumor cell line was quantified by flow cytometry using FITCconjugated annexin V/propidium iodide (PI) (SIGMA San Diego USA). After the incubation of cells with either $10 \mu \mathrm{g} / \mathrm{ml} \mathrm{Aq,} 10 \mu \mathrm{g} / \mathrm{ml}$ EA or Q3ME $10 \mu \mathrm{g} / \mathrm{ml}$ for $24 \mathrm{~h}$, cells were washed twice with PBS, resuspended in binding buffer (10 mM HEPES, $140 \mathrm{mM} \mathrm{NaCl}, 2.5 \mathrm{mM} \mathrm{CaCl}_{2}$, $\mathrm{pH}$ 7.4) at a concentration of $1 \times 10^{6}$ cells/ml Aliquots of $1 \times 10^{5}$ treated cells were incubated with annexin-FITC and propidium iodide for $15 \mathrm{~min}$ at room temperature in the dark. Samples were shaken gently, diluted in binding buffer and analyzed by flow cytometry within $1 \mathrm{~h}$. Cells treated with culture medium alone (basal conditions) and fixed with $2.3 \%$ ethanol were used as controls. At least 10,000 events per tube were acquired in a Becton-Dickinson FACSCaliburflow cytometer (Becton Dickinson Biosciences, San José, CA.) The data analysis was performed on the FCS Express V3 platform, plotting FL1 (annexin-V-FITC) against FL2 
(IP). The results were expressed as percentage of cells \pm standard deviation of the total of cells acquired (Davicino et al. 2010).

\section{Determination of the expression of STAT 3 by Western blot}

B16F10 cells were cultured in either the absence or the presence of either EA $(100 \mu \mathrm{g} / \mathrm{ml})$, Q3ME $(10 \mu \mathrm{g} / \mathrm{ml})$, DPP $(10 \mu \mathrm{M})$ or IL-6 $(10 \mathrm{ng} / \mathrm{ml})$ for $24 \mathrm{~h}$. Cells were then lysed for $30 \mathrm{~min}$ at $4{ }^{\circ} \mathrm{C}$ with lysis buffer $(50 \mathrm{mmol} / 1$ Tris- $\mathrm{HCl}, 150 \mathrm{mmol} / 1 \mathrm{NaCl}, 1 \mathrm{mmol} / 1$ EGTA, $1 \% \mathrm{NP}-40,1$ $\mathrm{mmol} / 1 \mathrm{NaF}, \quad 1 \quad \mathrm{mmol} / 1 \quad \mathrm{Na}_{3} \mathrm{VO}_{4}, \quad 0.25 \%$ sodium deoxycholate, $1 \mu \mathrm{mol} / 1$ phenylmethylsulfonylfluoride, $10 \mu \mathrm{g} / \mathrm{ml}$ aprotinin, $10 \mu \mathrm{mol} / 1$ pepstatin and $10 \mu \mathrm{mol} / 1$ leupeptin). After centrifugation $\left(14,000 \mathrm{xg}, 15 \mathrm{~min}, 4^{\circ} \mathrm{C}\right)$, whole-cell protein extracts $(50 \mu \mathrm{g})$ were mixed with sample buffer (2\% SDS, 10\% v/v glycerol, 62.5 mMTris-HCl, $\mathrm{pH} 6.8,0.2 \%$ bromophenol blue and 1\% v/v 2-mercaptoethanol). Equal amounts of protein were separated by SDS-PAGE on $10 \%$ polyacrylamide gels and transferred to a PVDF membrane. Non-specific binding sites were blocked with blocking buffer (5\% non-fat dried milk containing $0.1 \%$ Tween 20 in 100 mMTris- $\mathrm{HCl}, \mathrm{pH} 7.5$ and $0.9 \% \mathrm{NaCl}$ ) for $1 \mathrm{~h}$. Membranes were then incubated overnight with a mouse antibody anti-active phospho-STAT3 and antibody anti-STAT3 (Santa Cruz Biotech). After washing with PBS-Tween, membranes were sequentially incubated with a horseradish peroxidase-conjugated anti-mouse antibody $(1: 2500)$ for $1 \mathrm{~h}$. After washing with PBS-Tween, the immunological reaction was developed with an enhanced chemiluminescent system. Band intensities were normalized to those of total STAT3. The densitometric analysis of bands was performed using the Image J software (version 5.1, Silk Scientific Corporation, NIH, Bethesda, MA, US), and expressed as p-STAT3/ total STAT3 (arbitrary units) (Park et al. 2014).

\section{Statistical analysis}

The Student's $t$ test for unpaired measures was used to determine the level of significance of results. When multiple comparisons were necessary, one way ANOVA plus the Dunnett or Tukey's test was applied. Differences between means were considered significant when $p<0.05$.

\section{References}

Alexander B, Browse DJ, Reading SJ, Benjamin IS. 1999. A simple and accurate mathematical methods for calculation of the $\mathrm{EC}_{50}$. J Pharmacol Toxicol Methods. 41(2):55-58.

Anesini C, Genaro A, Cremaschi G, Sterin Borda L, Cazux C, Borda E. 1996. Immunomodulatory activity of Larrea divaricata Cav. Fitoterapia. 67:329-333.

Davicino R, Alonso R, Anesini C. 2011. "In vivo" and "in vitro" activity of Larrea divaricata Cav. on EL-4 cells. Hum Exp Toxicol. 30(8):965-971. https://doi.org/10.1177/0960327110384523. 
Davicino R, Manuele MG, Turner S, Ferraro G, Anesini C. 2010. Antiproliferative activity of Larrea divaricata Cav. on lymphoma cell line: participation of hydrogen peroxide in its action. Cancer Invest. 28(1):13-22. doi: 10.3109/07357900902849665.

Hosseinzadeh R, Khorsandi K, Hemmaty S. 2013. Study of the effect of surfactants on extraction and determination of polyphenolic compounds and antioxidant capacity of fruits extracts. PLoS ONE. 8(3):e57353. doi: 10.1371/ journal.pone.0057353.

Park JS, Bang OS, Kim J. 2014. Screening of Stat3 inhibitory effects of Korean herbal medicines in the A549 human lung cancer cell line. Integr Med Res. 3(2):67-73. doi: 10.1016/j.imr.2013.10.004.

Table S1. Content of polyphenols, Q3ME, NDGA and 4-HBA in Aq and EA

\begin{tabular}{|c|c|c|c|c|c|}
\hline Extracts & $\begin{array}{c}\text { Yield } \\
(\%)\end{array}$ & $\begin{array}{c}\text { Polyphenols } \\
\text { g\%* }\end{array}$ & $\begin{array}{c}\text { NDGA } \\
\text { g\% }\end{array}$ & $\begin{array}{c}\text { Q3ME } \\
\text { g\% }\end{array}$ & $\begin{array}{c}\text { 4-HBA } \\
\text { g\% }\end{array}$ \\
\hline Aq & 26.6 & $11.7 \pm 1.6^{\mathrm{a}}$ & $\mathbf{0 . 8 0} \pm 0.05^{\mathrm{a}}$ & ---- & $\mathbf{0 . 0 3 4 3} \pm 0.003^{\mathrm{a}}$ \\
\hline EA & 3.83 & $50.24 \pm 2.13^{\mathrm{b}}$ & $3.22 \pm 0.40^{\mathrm{b}}$ & $\mathbf{0 . 5 2} \pm 0.03$ & $1.3 \pm \mathbf{0 . 1 0}^{\mathrm{b}}$ \\
\hline
\end{tabular}

Polyphenols were determined by spectroscopic methods, NDGA, 4-HBA and Q3ME were determined by HPLC-UV. Values are expressed as mean \pm SEM of three independent measures. * Gallic acid equivalent. a and $\mathrm{b}$ significant differences ( $\mathrm{p}<0.001$, Student's $t$ test.)

Table S2. EC 50 values for the antiproliferative activity of Aq, EA, Q3ME and NDGA

\begin{tabular}{|c|c|}
\hline Extracts /Compounds & EC $_{50}(\mu \mathrm{g} / \mathrm{ml})$ \\
\hline $\mathrm{Aq}$ & $316 \pm 30 \mu \mathrm{g} / \mathrm{ml}^{\mathbf{a}}$ \\
\hline EA & $\leq 0.1 \mu \mathrm{g} / \mathrm{ml}^{\mathbf{b}}$ \\
\hline Q3ME & $<0.1 \mu \mathrm{g} / \mathrm{ml}^{\mathbf{b}}$ \\
\hline NDGA & $2.3 \pm 0.2 \mu \mathrm{g} / \mathrm{ml}^{\mathbf{c}}$ \\
\hline
\end{tabular}

$\mathrm{EC}_{50}$ values $(\mu \mathrm{g} / \mathrm{ml})$ were calculated from concentration $v s$. effect graphs (Figure 1) by the Alexander's method. Results are expressed as mean \pm SEM of three experiments made in triplicate. a,b,c significant differences between treatments (One way ANOVA plus Tukey's multiple comparison test). 
A

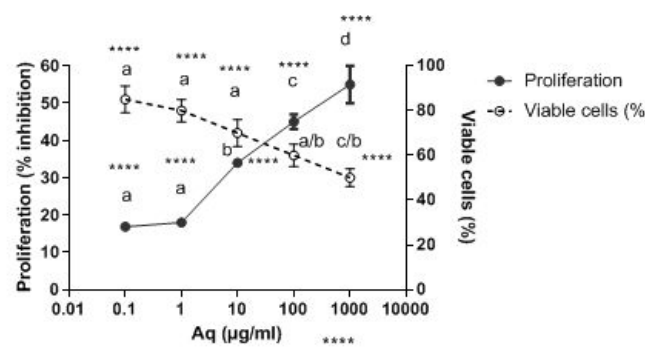

C
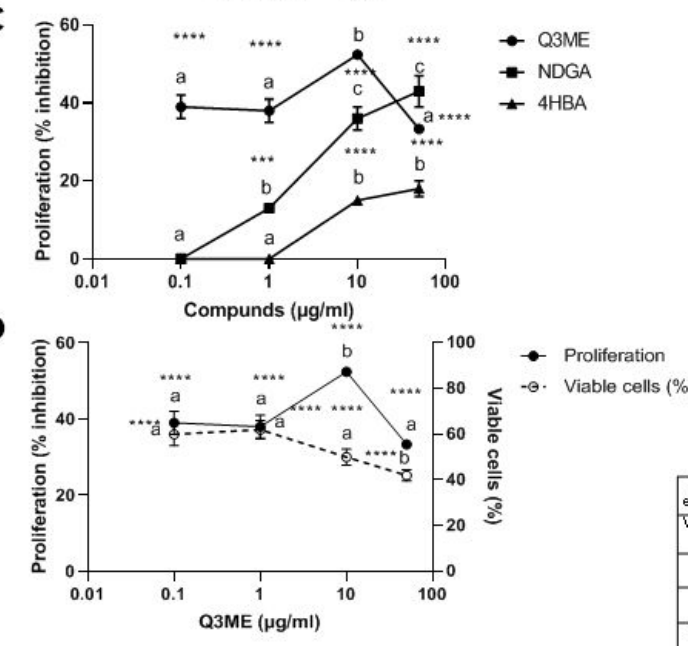

B

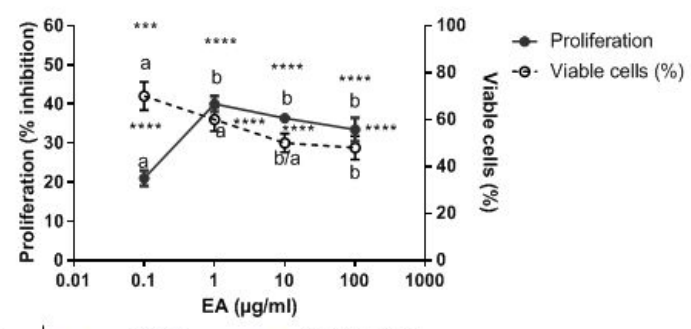

E

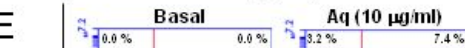

Figure S1.Effect of Aq, EA, Q3ME, 4-HBA and NDGA on the proliferation and viability of B16F10 melanoma cells. Cells were incubated for $24 \mathrm{~h}$ in the presence of Aq (A), EA (B), Q3ME, 4-HBA and NDGA (C). D: effect of Q3ME on cell proliferation and viability. E: Representative flow cytometry analysis of three experiments. Results are expressed as mean \pm SEM of three experiments made in triplicate. a,b,c significant differences (One way ANOVA plus Tukey's multiple comparison test). Table embedded: Percentage of viable cells and apoptotic cells obtained by flow cytometry. ${ }^{*} \mathrm{p}<0.05,{ }^{*} \mathrm{p}<0.01 ; * * * \mathrm{p}<0.001,{ }^{* * * *} \mathrm{p}<0.0001$ : significant differences with respect to basal values (One way ANOVA plus Dunnett's multiple comparison test), a, b significant differences (One way ANOVA plus Tukey's multiple comparison test). 
A

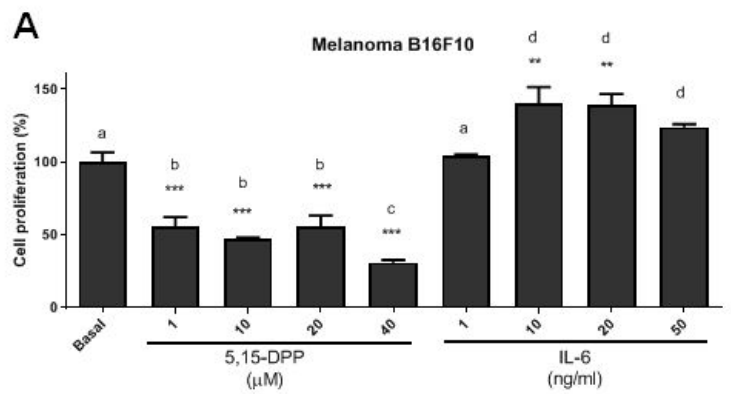

C

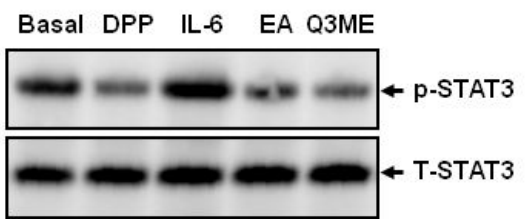

B

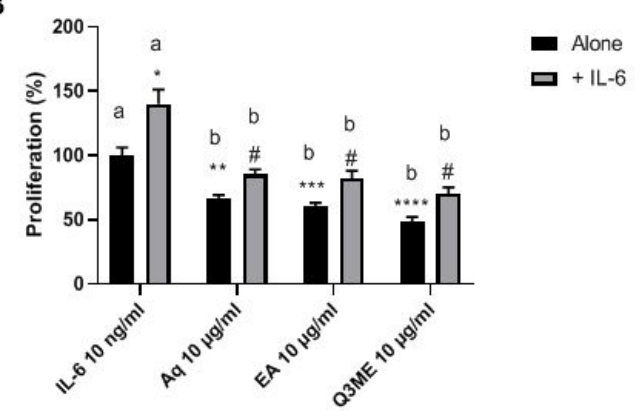

D

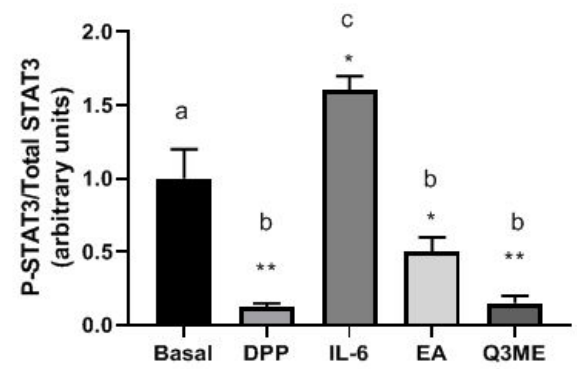

Figure S2. Effect of Aq, EA and Q3ME on p-STAT3 activation and expression in B16F10 melanoma cells.(A) Cells were incubated for $24 \mathrm{~h}$ with either IL-6 $(1 \mathrm{ng} / \mathrm{ml}, 10 \mathrm{ng} / \mathrm{ml}, 20$ $\mathrm{ng} / \mathrm{ml}$, and $50 \mathrm{ng} / \mathrm{ml})$, a STAT3 activator, or 5,15-DPP $(1 \mu \mathrm{M}, 10 \mu \mathrm{M}, 20 \mu \mathrm{M}, 40 \mu \mathrm{M})$, a STAT3 inhibitor. (B) Cells were incubated for $24 \mathrm{~h}$ with either Aq, or EA or $10 \mu \mathrm{g} / \mathrm{ml} \mathrm{Q3ME}$ alone or in the presence of $10 \mathrm{ng} / \mathrm{ml} \mathrm{IL-6.} \mathrm{(C)} \mathrm{Western} \mathrm{blot} \mathrm{analysis} \mathrm{of} \mathrm{p-STAT3} \mathrm{and} \mathrm{(E)} \mathrm{densitometric}$ analysis: T-STAT3 and p-STAT3/T-STAT3 (arbitrary units). B16F10 cells were incubated for $24 \mathrm{~h}$ with either EA $(100 \mu \mathrm{g} / \mathrm{ml})$ or Q3ME $(10 \mu \mathrm{g} / \mathrm{ml})$, or $10 \mu \mathrm{M} 5.15 \mathrm{DPP}$ or $10 \mathrm{ng} / \mathrm{ml}$ IL-6. pSTAT3: phosphorylated STAT3; T-STAT3: total-STAT3. Results are expressed as mean \pm SEM of three experiments performed in triplicate. ${ }^{* * *} \mathrm{p}<0.001,{ }^{*} \mathrm{p}<0.01,{ }^{*} \mathrm{p}<0.05$ : significant differences between basal and post-treatment values, $\# p<0.05$ : significant differences between treatments in the presence of IL- 6 and IL- 6 alone (ANOVA followed by the Dunnett's multiple comparison test). a,b,c, significant differences (Tukey's multiple comparisons test). 